\title{
Research on Subject Construction in Provincial University
}

\author{
Chang Xin \\ School of Municipal \& Environmental Engineering \\ Jilin Jianzhu University \\ Changchun, P.R.China \\ 460538063@qq.com
}

\author{
Zhao Zengquan \\ School of Marxism \\ Changchun University \\ Changchun, P.R.China \\ xiaobaitu668@sina.com
}

\begin{abstract}
Subject construction has been a complex system engineering of colleges and universities. The subject construction of local engineering colleges in China are facing many propositions, such as the determination of subject status, the perfection of subject structure, the improvement of subject organization and the final establishment of subject institution. This paper discusses several aspects important for subject construction starting from the current situation of subject construction and in combination with the actual situation of subject construction in Jilin Jianzhu University, so as to ensure the competitiveness of subject construction in provincial university.
\end{abstract}

Keywords-provincial university; subject construction; research

\section{INTRODUCTION}

Along with the establishment and perfection of the socialist market economy mechanism, colleges and universities will face larger challenges and the competition will be intensified. Being at a disadvantage in the competition, provincial universities have to face and consider the issue of making their graduates, research achievements and technology products recognized and accepted by society, so as to attract social attention and obtain enough economic support and then strengthen their schooling strength and competitiveness. Subject construction has attracted much attention from colleges and universities at home and abroad, because it is a foundation for provincial universities to solve the above issues[1-2].

\section{CURRENT STATUS OF SUBJECT CONSTRUCTION IN LOCAL ENGINEERING COLLEGES}

Limited by their own conditions and financial resources, it is difficult for local engineering colleges to compete with key university in terms of talents, academic achievements and scientific research funds. However, provincial universities still pursue blindly the operation model for key universities, which is characterized by large scale, complete subjects and high level. It should be avoided in the subject construction of provincial universities.

\section{A. Blind setting of subjects}

There is no reliable subject basis for subject setting, the guiding thought is not clear, subjects are increased blindly, the background conditions of the new subjects are not fully recognized and the setting of subjects is not conducted from the perspective of social needs. Therefore, new subjects develop slowly, even some subjects cannot guarantee the normal teaching requirements, there is a big obstacle for graduates to seek a job, and the setting does not meet the target of higher education for training the personnel needed by the society.

\section{B. Inaccurate subject orientation}

Some colleges or universities may not have their own accurate positioning and direction in subject construction, not recognize the characteristics of their own subject, school, industry and region, not develop long-term, stable and sustainable direction for the scientific development of the subject, or reach for what is beyond their capability, not correspond with reality, or not have their own direction. All of these cannot be positioned as the subject construction direction of a unit.

\section{Weak strength of subject team}

Due to relatively weak subject basis, location in less developed area and low pay for teachers, the hardest problem in subject team construction is that the conditions are not attractive enough to talents. The rights and obligations of the subject leader are not clear, the selection, appointment and training of the subject leader are not institutionalized, and thus team construction lags behind..

\section{Backward basis of subject construction}

The key point of subject construction is laboratory construction. Local colleges always have many problems to deal with laboratory construction due to lack of funds. The present situation is that the experimental facilities are oldfashioned and fall behind the times, and both quantity and usable area are not enough. With the increase in the number of enrollment, there are serious difficulties to satisfy the needs of course teaching completely, and it is impossible to provide reliable support to scientific research work, which seriously restricts subject construction.

\section{SOME IDEAS ON THE SUBJECT CONSTRUCTION OF LOCAL ENGINEERING COLLEGES}

\section{A. The subject setting should be suitable to actual circumstances}

On one hand, the subject setting should comply with social needs, because the needs of developing society for talents also develop from singleness to multi-subject, crosssubject and multi-level comprehensive requirements. Taking building environment and energy application engineering subject as an example, it is required that students should master the knowledge related to professional system and the 
selection, calculation, design and construction supervision of equipments. Now the subject area is widened, so it is necessary to master much more knowledge in engineering economy and system control. Its purpose is to satisfy the demands of construction market for the technical talents of the subject at present as well as in the short and medium terms. On the other hand, the subject setting should be based on their own conditions. In recent years, the expansion of colleges and universities has resulted in the enlargement of subject setting. Generally speaking, these new subjects are set up by colleges and universities relying on their original school-running characteristics and direction as well as the existing subjects. Meanwhile, the new subjects basically comply with the demands of society and market. But to some extent, there is the tendency to desire for large and foreign scale as well as large quantity. Taking our school as an example, the original basis is construction engineering college, and social sciences, foreign language, computer and other subjects have been increased in recent year. Many problems occur in the process of talent training, such as insufficient teaching strength and resources as well as shallow subject background, some of which may affect the employment of graduates. This reflects that a detailed feasibility analysis is not conducted for the setting of new subjects, and thus new subjects cannot depend on the original preponderant subjects. Therefore, the expansion of subjects cannot be regarded as successful.

\section{B. The direction of subject should strengthen the traction of needs}

Subject direction construction is the basis of subject construction, and subject construction should hold the direction of subjects properly. The most basic principle for the subject direction construction of colleges and universities should also be the principle of social demands. That is to say, subject direction setting as well as talent training quality and scale must take economic construction and social overall development as the starting point and destination. Now we take the building environment and energy application engineering of Jilin Jianzhu University as an example. According to China' s current development situation, in subject direction construction, Jilin Jianzhu University should formulate subject direction always according to the guiding ideologies of scientific development concept and sustainable development, and determine the integrated application of energy saving, emission reduction, " four savings" and renewable energy, namely to take the direction of integration with building as the subject direction.

\section{The subject team should strength the comprehensive level of echelon}

The subject team construction is the key of subject construction. To ensure continuous and stable development of a subject, a subject team with reasonable age, educational background and professional title structure is very important. Firstly it needs to have subject leaders with high academic level and rich scholarship experiences. He (or they) serves this subject for a long time, engages in the teaching and scientific research work of the subject for many years, has a good understanding of the subject, obtains fruitful teaching and scientific research achievements, understands the frontier issues of the subject, and thus he (or they) can lead the subject team to carry out highly effective teaching and scientific research activities. The subject team should have reasonable personnel number and echelon structure, and it can be competent for all kinds of teaching and scientific research work at all levels required by subject construction..

\section{The infrastructure of subject should strengthen the support}

Subject construction relies on subject basis construction. Subject basis construction refers to laboratory construction, practice teaching base construction and teaching material construction. The laboratory construction should first increase financial support, so as to meet the experimental teaching needs of the subject, i.e., the laboratory should be completely open to the students for developing design and comprehensive experiment projects. The number of experimental equipments as well as scientific and technological content should meet the demands of students in this subject and other related subjects for comprehensively carrying out the experiments; meanwhile, they should give strong support for conducting the scientific research projects of the subject. The scientific research and laboratory construction should supplement each other and make progress together, so as to constantly improve the experimental means and experimental level [3-5].

Experimental teaching base is one of the indispensable important conditions in the practical teaching activities of subject. One subject should have its own practical teaching base which is stable and adapt to the development of subject. This base should be able to provide the students with the practical opportunities of using hands and brain according to subject training plan. In this way, students (especially students majoring in engineering) can further deepen and intensify the theory and the knowledge learned in practical teaching base. What' s more, they can combine the theory and practice, and thus understand and grasp the practical problems of the subject when learning in schools.

The construction of textbook material is the basis which is related to the teaching of theory courses. In addition to completely and systematically discussing the basic theory, calculation and methods of the course, one good book should focus on the connection, integration and comprehension of other courses in the subject, and thus play a role in connecting the preceding and the following. Meanwhile, the teaching material should reflect properly the new theory, technology, methods, materials and equipments involved in the course. In this way, students can understand the development of the subject as soon as possible, especially the development trend, which can help students apply the knowledge to work after graduating from university.

\section{CONCLUSION}

In conclusion, local engineering colleges should start from their own actual conditions, take root in and serve this area, obtain the local support relying on services and achieve self-development relying on contribution, so as to expand its 
development space constantly and realize the long-term development of the local engineering colleges.

\section{REFERENCES}

[1] Wang Mei,Wang Yiran,Chen Shijun, "Study on the construction of university discipline in China: present situation, problems and Prospect,” Higher Education Exploration, pp. 106-109, February 2008.
[2] Wang Mei,Chen Shijun,Wang Yiran, "Research on discipline construction in Universities," Journal of China University of Geosciences,2006.

[3] Sun Qingzhong, "The discipline construction of research university in our country,” Social Scientist,pp. 129-131,April 2008.

[4] Ji Ping,Yang Tingting,Li song, "Research on the subject construction of University,” Modern Distance Education,pp. 28-33,February 2012.

[5] Jiang Huiyun,Chen Jinyan, "The first-class discipline construction of Research University,"Higher Agricultural Education,pp. 4042,November 2013. 